\title{
RESEARCH PAPER \\ Evaluation of DMI fungicides against species of Diplodia and Neofusicoccum associated with Botryosphaeria canker of grapevine
}

\section{Carolina Torres ${ }^{1}$, Bernardo A. Latorre $^{2}$, Pedro Undurraga ${ }^{1}$, and Ximena Besoain $^{1}$}

${ }^{1}$ Facultad de Agronomía, Pontificia Universidad Católica de Valparaíso. Casilla 4-D, Quillota, Chile. ${ }^{2}$ Facultad de Agronomía e Ingeniería Forestal, Pontificia Universidad Católica de Chile. Casilla 306-22, Santiago, Chile.

\begin{abstract}
C. Torres, B.A. Latorre, P. Undurraga, and X. Besoain. 2013. Evaluation of DMI fungicides against species of Diplodia and Neofusicoccum associated with Botryosphaeria canker of grapevine. Cien. Inv. Agr. 40(1):131-138. The Botryosphaeriaceae species have been widely studied and are considered a serious problem to the production of grapes worldwide. To aid in the development of control strategies for these fungi, in vitro experiments were conducted to evaluate the effectiveness of demethylation inhibiting (DMI) fungicides against Diplodia seriata, D. mutila, Neofusicoccum australe and N. parvum isolated from grapevine (Vitis vinifera). Fungicidal effectiveness was evaluated over a range of increasing concentrations using measurements of both the inhibition of conidial germination and the effects on mycelial growth. The effective concentrations (EC) necessary to inhibit conidial germination and mycelial growth by $50 \%\left(\mathrm{EC}_{50}\right)$ and $90 \%\left(\mathrm{EC}_{90}\right)$ were estimated by linear regression analysis between $\mathrm{x}=\log _{10}$ of the fungicidal concentration and $\mathrm{y}=$ the Probit value of the inhibition percentage. The results demonstrate that tebuconazole, myclobutanil, prochlorazand prochloraz plus epoxiconazole exhibit considerable in vitro activity against $D$. mutila, D. seriata, $N$. australe and $N$. parvum. These DMI compounds were able to arrest conidial germination and inhibit mycelial growth. The $\mathrm{EC}_{50}$ values obtained for conidial germination were generally higher than the $\mathrm{EC}_{50}$ values obtained for mycelial growth, suggesting that mycelia are more sensitive to the DMI compounds than are conidia. However, the effectiveness of these DMI compounds in the vineyard must be studied before any final conclusions can be reached.
\end{abstract}

Key words: Black dead arm, bot canker, fungicides, myclobutanil, prochloraz, tebuconazole.

\section{Introduction}

In recent years, the various fungal species of the Botryosphaeriaceae family have gained

Received August 1, 2012. Accepted January 18, 2013. Corresponding author: xbesoain@ucv.cl in importance as they have been consistently associated with Botryosphaeria canker and other trunk diseases of grapevine (Vitis vinifera L.) (Úrbez-Torres, 2011). The symptoms of these diseases include short internodes, dead spurs, dead arms and dieback associated with brown $\mathrm{V}$-shaped cankers of hard consistency, which is always 
observed internally in the trunks and arms of the vines. Wood symptoms progress slowly and lead to gradual reductions in vigor and yields. These symptoms can be very severe in stressed plants, causing apparent effects in a short period of time (Pusey, 1989; Ma et al., 2001; Larignon et al., 2009).

Among the species of Botryosphaeriaceae, Diplodia mutila (Teleomorph Botryosphaeria stevensii), D. seriata (Teleomorph B. obtusa), Neofusicoccum australe (Teleomorph $B$. australe) and $N$. parvum (Teleomorph B. parva) are recognized worldwide as the main causal agents of trunk diseases in grapevine (Úrbez-Torres, 2011). In Chile, D. mutila, $D$. seriata, $N$. australe and $N$. parvum have all been reported as economically important pathogens of grapevine (Auger et al., 2004; Díaz et al., 2011; Morales et al., 2012; Besoain et al., 2013). Of these species, D. mutila appears to be the most aggressive on table grapes (Morales et al., 2012).

Control methods for diseases associated with Botryosphaeriaceae in grapevines are limited. The treatments that do exist focus on the protection of pruning wounds, which are considered primary infection sites (Van Niekerk et al., 2006, 2007; Sierra et al., 2008; Úrbez-Torres and Gubler, 2011). Several fungicides have been evaluated and proposed as wound protectants against species of Botryosphaeriaceae (Savocchia et al., 2005; Bester and Fourie, 2005; Bester et al., 2007; Auger et al., 2010; Pitt et al., 2012, Díaz and Latorre, 2013). Currently, demethylation inhibiting (DMI) fungicides, primarily triazoles, are used to control grapevine powdery mildew (Erysiphe necator), and some DMI fungicides (e.g., fenbuconazole, tebuconazole) are recommended for use against gray mold (Botrytis cinerea) of grapevines in Chile. Therefore, this study aimed to evaluate the in vitro effectiveness of the DMI fungicides commonly used in grapevines against the conidial and mycelial growth of species of Diplodia and Neofusicoccum.

\section{Materials and methods}

\section{Fungicides}

The following DMI fungicides were used in this study: difenoconazole (Dominio 25 EC, Anasac Chile), epoxiconazole (Technical product, Anasac Chile), fenbuconazole (Indar 2 F Dow AgoSciences, Chile), myclobutanil (Rally 2 EC, Dow AgroSciences, Chile), prochloraz Technical product, Anasac Chile), tebuconazole (Apolo $25 \mathrm{EW,}$ Anasac Chile) and a combination of prochloraz and epoxiconazole(Epro 25 EW, Anasac, Chile) (Table 1).

\section{Isolates and inoculum preparation}

In this study, D. mutila (isolates Vid 1476, Vid 1510 and Vid 1265), D. seriata (isolates Vid 1472, Vid 1468 and Vid 1270), N. australe (isolates Vid 1509 and Vid 1559) and N. parvum (isolates Vid $1471)$, all obtained from grapevines ( $V$. vinifera) affected by trunk diseases, were used. These isolates have been identified based on morphology and molecular data in previous works (Morales et al., 2012; Besoain et al., 2013).

Table 1. DMI Fungicides selected for in vitro sensitivity tests.

\begin{tabular}{llcll}
\hline Active ingredients & Trade Name & Concentration $^{1}(\mathrm{w} / \mathrm{v}), \%$ & DMI Group & Origin \\
\hline Difenoconazole & DOMINIO 25 EC & 2.5 & Triazole & Anasac Chile \\
Epoxiconazole & Technical product & 100.0 & Triazole & Anasac Chile \\
Fenbuconazole & INDAR 2 F & 2.4 & Triazole & Dow AgroSciences, Chile \\
Myclobutanil & RALLY 2 EC & 2.4 & Triazole & Dow AgroSciences, Chile \\
Prochloraz & Technical product & 100.0 & Imidazole & Anasac Chile \\
Prochloraz+epoxiconazole & EPRO 2000 EC & 2.0 & Imidazole+Triazole & Anasac Chile \\
Tebuconazole & APOLO 25 EW & 2.5 & Triazole & Anasac Chile \\
\hline
\end{tabular}

${ }^{1}$ Active ingredient concentration of the formulated product. 
Conidia were obtained from cultures grown in potato dextrose agar (Difco Laboratories, Detroit, MI) (PDA) plus $0.5 \mathrm{~mL}$ of $96 \%$ lactic acid (APDA) and incubated under ultraviolet $(\lambda=320 \mathrm{~nm}$ ) light at 20 to $22{ }^{\circ} \mathrm{C}$ for 30 days. Mycelial plugs were obtained from four day old cultures in APDA.

\section{Inhibition of conidial germination}

The conidial germination was studied in potato dextrose broth $(200 \mathrm{~g}$ of fresh potatoes were boiled in $1000 \mathrm{~mL}$ of water for $60 \mathrm{~min}$, and $20 \mathrm{~g}$ of dextrose were added to the resulting solution) acidified with $0.5 \mathrm{~mL}$ of $96 \%$ lactic acid (APDB). To this broth, $0.0,0.1,1.0,5.0,10.0$ or $50.0 \mathrm{mg} \mathrm{L}^{-1}$ of the above-mentioned fungicides were added. The tests were performed in individual wells of microtiter plates (96-well polystyrene plate, Nunc Polysorp, Roskilde, Denmark), with each well holding $50 \mu \mathrm{L}$ of APDB containing twice the final fungicide concentration plus $50 \mu \mathrm{L}$ of a $10^{5}$ conidia $\mathrm{mL}^{-1}$ suspension prepared in sterile distilled water (SDW) (Stammler and Speakman, 2006).

The microtiter plates were incubated at $23{ }^{\circ} \mathrm{C}$ for $48 \mathrm{~h}$ while being shaken continuously $(80 \mathrm{rpm})$ in an orbital shaker (Model AROS 160, Thermolyne, MA) to prevent fungicide precipitation. Afterwards, $30 \mu \mathrm{L}$ of solution were obtained from each well, and conidia germination was stabilized with $50 \%$ lactophenol blue solution (Merck, Darmstadt, Germany) before each sample was spread on a glass slide, covered with a glass coverslip and sealed with Entellan (Merck, Darmstadt, Germany).

The proportion of germinated conidia was determined in a sample of 20 conidia for each of the four replicates per fungicide concentration. Conidia were scored as germinated if the germ tube had attained 0.5 times the diameter of the conidia, excluding those conidia showing atrophied germ tubes (Stammler and Speakman, 2006). All experiments were repeated.

\section{Inhibition of mycelial growth}

The effect of each fungicide on mycelial radial growth was determined in APDA to which 0.0, $0.1,1.0,5.0,10.0,50.0$ and $100.0 \mathrm{mg} \mathrm{L}^{-1}$ of the fungicides had been added. Fungicides were added in esterile distilled water to autoclaved APDA cooled to $50^{\circ} \mathrm{C}$. Mycelial plugs $(8 \mathrm{~mm}$ in diameter) were placed, in triplicate, in the center of $9 \mathrm{~cm}$ diameter Petri plates and incubated at 25 ${ }^{\circ} \mathrm{C}$ for $72 \mathrm{~h}$ before the diameters of the colonies were measured. All experiments were repeated.

\section{Statistical analysis}

The median effective concentrations $\left(\mathrm{EC}_{50}\right)$ were determined, as well as the $90 \%$ inhibition levels $\left(\mathrm{EC}_{90}\right)$, using a linear regression analysis between $\mathrm{x}=\log _{10}$ of the fungicide and $\mathrm{y}=$ the Probit value of the percentage of inhibition. $\mathrm{EC}_{50}$ and $\mathrm{EC}_{90}$ were statistically analyzed for $D$. mutila, D. seriata and Neofusicucum spp. Analysis of variance was conducted to determine the effects of the three isolates, the seven fungicides and their respective interactions. The mean values were separated using the Tukey test $(\mathrm{P} \leq 0.05)$. The $\log _{10}$ $\mathrm{X}$ transformation was used when the data were not normally distributed. The software Infostat (Córdoba, Argentina) was used for all analysis.

\section{Results}

The analysis of variance for the $\mathrm{EC}_{50}$ values of conidial and mycelial growth inhibition showed that the $\mathrm{EC}_{50}$ values were significantly $(\mathrm{P} \leq 0.05)$ affected by fungicide treatments and isolates and by the interaction between fungicide treatments and isolates (Table 2). However, only fungicide was shown to have a significant $(\mathrm{P} \leq 0.05)$ effect in conidial growth inhibition for the two Neofusicoccum isolates (Table 3). 
Table 2. Effectiveness of demethylation inhibiting (DMI) fungicides in vitro against isolates of Diplodia mutila and D. seriata from grapevine.

\begin{tabular}{|c|c|c|c|c|c|c|c|c|}
\hline \multirow[b]{3}{*}{ Fungicides } & \multicolumn{8}{|c|}{ Median effective concentrations $\left(\mathrm{EC}_{50}\right), \mathrm{mg} \mathrm{L}^{-1}$} \\
\hline & \multicolumn{4}{|c|}{ D. mutila } & \multicolumn{4}{|c|}{ D. seriata } \\
\hline & Vid 1476 & Vid 1265 & Vid 1510 & Mean $^{1}$ & Vid 1472 & Vid 1468 & Vid 1270 & Mean $^{1}$ \\
\hline \multicolumn{9}{|l|}{ Conidial germination inhibition } \\
\hline Difeconazole & $1.3 \mathrm{a}^{2}$ & - & $5.0 \mathrm{~b}^{2}$ & $3.2 \pm 2.6$ & ne & ne & ne & \\
\hline Epoxiconazole & ne & - & ne & & $8.1 \mathrm{a}^{2}$ & $1.7 \mathrm{a}^{2}$ & $>100 \mathrm{~b}^{2}$ & $36.6 \pm 55.0$ \\
\hline Fenbuconazole & ne & - & ne & & ne & ne & ne & \\
\hline Myclobutanil & $0.4 \mathrm{a}$ & - & $1.6 \mathrm{a}$ & $1.0 \pm 0.8$ & $0.5 \mathrm{a}$ & $2.2 \mathrm{a}$ & $1.0 \mathrm{a}$ & $1.2 \pm 0.9$ \\
\hline Prochloraz & $1.2 \mathrm{a}$ & - & $1.4 \mathrm{a}$ & $1.3 \pm 0.1$ & $5.5 \mathrm{a}$ & $0.4 \mathrm{a}$ & $0.2 \mathrm{a}$ & $2.0 \pm 3.0$ \\
\hline Prochloraz + epoxiconazole & $0.4 \mathrm{a}$ & - & $0.2 \mathrm{a}$ & $0.3 \pm 0.1$ & $0.8 \mathrm{a}$ & $0.1 \mathrm{a}$ & $1.0 \mathrm{a}$ & $0.6 \pm 0.5$ \\
\hline Tebuconazole & $0.5 \mathrm{a}$ & - & $1.0 \mathrm{a}$ & $0.8 \pm 0.4$ & $0.3 \mathrm{a}$ & $0.3 \mathrm{a}$ & $0.5 \mathrm{a}$ & $0.4 \pm 0.1$ \\
\hline \multicolumn{9}{|l|}{ Mycelial growth inhibition } \\
\hline Difeconazole & $0.1 \mathrm{a}^{2}$ & $0.2 \mathrm{a}^{2}$ & $0.1 \mathrm{a}^{2}$ & $0.1 \pm 0.1$ & $0.2 \mathrm{a}^{2}$ & $0.7 \mathrm{a}^{2}$ & $8.0 \mathrm{a}^{2}$ & $3.0 \pm 4.4$ \\
\hline Epoxiconazole & $1.0 \mathrm{a}$ & $7.0 \mathrm{~b}$ & $0.5 \mathrm{a}$ & $2.8 \pm 3.6$ & $1.0 \mathrm{a}$ & $0.3 \mathrm{a}$ & $0.7 \mathrm{a}$ & $0.7 \pm 0.4$ \\
\hline Fenbuconazole & $2.0 \mathrm{a}$ & $2.0 \mathrm{a}$ & $5.5 \mathrm{~b}$ & $3.2 \pm 2.0$ & $40.2 \mathrm{~b}$ & $>100 \mathrm{c}$ & $10.0 \mathrm{a}$ & $50.1 \pm 45.8$ \\
\hline Myclobutanil & $0.5 \mathrm{a}$ & $0.6 \mathrm{a}$ & $1.0 \mathrm{a}$ & $0.7 \pm 0.3$ & $1.0 \mathrm{a}$ & $0.8 \mathrm{a}$ & $1.1 \mathrm{a}$ & $1.0 \pm 0.2$ \\
\hline Prochloraz & $<0.1 \mathrm{a}$ & $1.0 \mathrm{a}$ & $0.1 \mathrm{a}$ & $0.4 \pm 0.5$ & $<0.1 \mathrm{a}$ & $<0.1 \mathrm{a}$ & $<0.1 \mathrm{a}$ & $0.1 \pm 0.0$ \\
\hline Prochloraz + epoxiconazole & $<0.1 \mathrm{a}$ & $0.1 \mathrm{a}$ & $0.1 \mathrm{a}$ & $0.1 \pm 0.0$ & $0.6 \mathrm{a}$ & $0.4 \mathrm{a}$ & $0.5 \mathrm{a}$ & $0.5 \pm 0.1$ \\
\hline Tebuconazole & $0.1 \mathrm{a}$ & $0.1 \mathrm{a}$ & $0.1 \mathrm{a}$ & $0.1 \pm 0.0$ & $0.3 \mathrm{a}$ & $0.3 \mathrm{a}$ & $0.3 \mathrm{a}$ & $0.3 \pm 0.0$ \\
\hline
\end{tabular}

${ }^{1}$ Mean \pm standard deviation.

${ }^{2}$ Means of the three replicates followed by the same letters are not significantly different according to Tukey's tests (P $\leq$ 0.05). ne: not effective at the fungicide concentrations tested. -: not tested.

Table 3. Effectiveness of demethylation inhibiting (DMI) fungicides in vitro against isolates of Neofusicoccum australe and N. parvum from grapevines.

\begin{tabular}{|c|c|c|c|c|}
\hline \multirow[b]{2}{*}{ Fungicides } & \multicolumn{3}{|c|}{ N. australe } & \multirow{2}{*}{$\begin{array}{l}\text { N. parvum } \\
\text { Vid } 1471\end{array}$} \\
\hline & Vid 1509 & Vid 1559 & Mean $^{1}$ & \\
\hline \multicolumn{5}{|l|}{ Conidial germination inhibition } \\
\hline Difeconazole & $0.7 \mathrm{~b}$ & & & $2.4 \mathrm{~b}$ \\
\hline Epoxiconazole & ne & - & - & ne \\
\hline Fenbuconazole & ne & - & - & ne \\
\hline Myclobutanil & $0.4 \mathrm{ab}$ & - & - & $1.1 \mathrm{ab}$ \\
\hline Prochloraz & $<0.1 \mathrm{a}$ & - & - & $<0.1 \mathrm{a}$ \\
\hline Prochloraz + epoxiconazole & $0.5 \mathrm{ab}$ & - & - & $1.5 \mathrm{ab}$ \\
\hline Tebuconazole & $0.3 \mathrm{a}$ & - & - & $0.4 \mathrm{a}$ \\
\hline \multicolumn{5}{|l|}{ Mycelial growth inhibition } \\
\hline Difeconazole & $0.3 \mathrm{ab}$ & $0.3 \mathrm{ab}$ & $0.3 \pm 0.0$ & $<0.1 \mathrm{a}$ \\
\hline Epoxiconazole & 0.9 abcd & $0.5 \mathrm{abc}$ & $0.7 \pm 0.3$ & $0.1 \mathrm{ab}$ \\
\hline Fenbuconazole & 1.3 bcde & $2.0 \mathrm{de}$ & $1.7 \pm 0.5$ & $0.3 \mathrm{ab}$ \\
\hline Myclobutanil & 1.7 cde & $2.4 \mathrm{e}$ & $2.1 \pm 0.5$ & 1.7 cde \\
\hline Prochloraz & $0.3 \mathrm{ab}$ & $0.1 \mathrm{ab}$ & $0.2 \pm 0.1$ & $<0.1 \mathrm{ab}$ \\
\hline Prochloraz + epoxiconazole & $0.4 \mathrm{ab}$ & $0.2 \mathrm{ab}$ & $0.3 \pm 0.1$ & $0.1 \mathrm{ab}$ \\
\hline Tebuconazole & $0.4 \mathrm{ab}$ & $<0.1 \mathrm{a}$ & $0.3 \pm 0.2$ & $0.4 \mathrm{ab}$ \\
\hline
\end{tabular}

${ }^{1}$ Mean \pm standard deviation.

${ }^{2}$ Means of the three replicates followed by the same letters are not significantly different according to Tukey's tests $(\mathrm{P} \leq 0.05)$. ne: not effective at the fungicide concentrations tested. -: not tested. 


\section{Inhibition of conidial germination}

The germination of conidia was observed after 30 days of incubation at $22{ }^{\circ} \mathrm{C}$, and the conidia had developed long and thin germination tubes (Figure 1). Non-germinated conidia and conidia exhibiting relatively short germ tubes were obtained on APDB amended with the DMI fungicides (Figure 1).

Independently of the isolates, difenoconazole, myclobutanil, prochloraz, prochloraz in combination with epoxiconazole, and tebuconazole all inhibited conidial germinations of $D$. mutila, with mean $\mathrm{EC}_{50}$ values ranging between $0.3 \pm 0.1$ and $3.2 \pm 2.6$ $\mathrm{mg} \mathrm{L}^{-1}$ (Table 2). The $\mathrm{EC}_{90}$ values for the conidial germination of D. mutila ranged from 0.8 to 49.0 $m g \mathrm{~L}^{-1}$ (data not shown)., The conidial germination of $D$. seriata was also inhibited by the same fungicides that were effective against the conidial germination of $D$. mutila, with the exception of difenoconazole. Although epoxiconazole did inhibit the conidial germination of $D$. seriata, considerably differences were observed among its isolates, with a mean $\mathrm{EC}_{50}$ of $36.6 \pm 55.0 \mathrm{mg}$ $\mathrm{L}^{-1}$ (Table 2) and $\mathrm{EC}_{90}$ values ranging from 6.3 to $>100 \mathrm{mg} \mathrm{L}^{-1}$.

The conidial germination of $N$. australe and $N$. parvum were inhibited by difenoconazole, myclobutanil, prochloraz, prochloraz in combination with epoxiconazole, and tebuconazole, with $\mathrm{EC}_{50}$ values ranging from $<0.1$ to $0.7 \mathrm{mg} \mathrm{L}^{-1}$ and from $<0.1$ to $2.4 \mathrm{mg} \mathrm{L}^{-1}$ in $N$. australe and $N$. parvum,
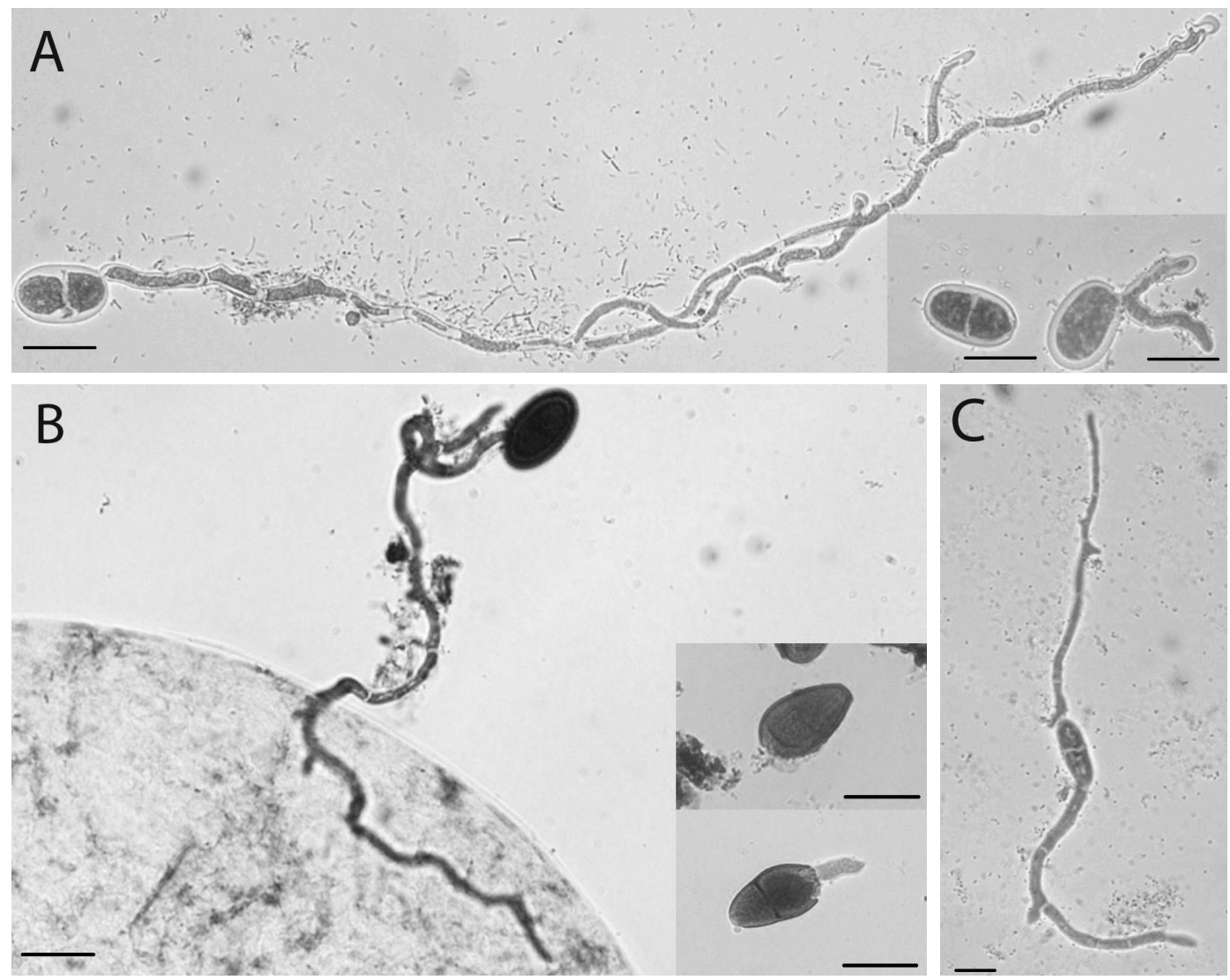

Figure 1. A. Germinated conidia of Diplodia mutila exhibiting long normal germ tubes after 30 days of incubation at $22^{\circ} \mathrm{C}$, with examples of non-germinated spores in the inset. Bars $=20 \mu \mathrm{m}$. B. Germinated conidia of $D$. seriata. Nongerminated conidia and conidia with a short anormal germination tube in the inset. Bars $=20 \mu \mathrm{m} \mathrm{C}$. Germinated conidia of Neofusicoccum parvum. Bars $=10 \mu \mathrm{m}$. 
respectively (Table 3 ). The $\mathrm{EC}_{90}$ values ranged from $<0.1$ to 6.1 and from $<0.1$ to $6.3 \mathrm{mg} \mathrm{L}^{-1}$ for $N$. australe and $N$. parvum, respectively (data not shown).

\section{Inhibition of mycelial growth}

The radial mycelial growth of the isolates of D. mutila and D. seriata was inhibited by difenoconazole, epoxiconazole, fenbuconazole, myclobutanil, prochloraz, prochloraz in combination with epoxiconazole, and tebuconazole, with mean $\mathrm{EC}_{50}$ values ranging from $0.1 \pm 0.0$ to $3.2 \mathrm{mg} \mathrm{L}^{-1}$ and from $0.1 \pm 0.0$ to $50.1 \pm 45.8 \mathrm{mg} \mathrm{L}^{-1}$ for $D$. mutila and $D$. seriata, respectively (Table 2 ). The $\mathrm{EC}_{90}$ values varied from 1.0 to $>100 \mathrm{mg} \mathrm{L}^{-1}$ and from 2.4 to $>100$ for D. mutila and D. seriata, respectively (data not shown).

All of the DMI fungicides inhibited the radial mycelial growth of $N$. australe and $N$. parvum, with mean $\mathrm{EC}_{50}$ values ranging from $0.2 \pm 0.1$ to $2.1 \pm 0.5 \mathrm{mg} \mathrm{L}^{-1}$ for $N$. australe and from $<0.1$ to $1.7 \mathrm{mg} \mathrm{L}^{-1}$ for $N$. parvum (Table 3). The $\mathrm{EC}_{90}$ values ranged from 0.5 to $>100$ and from 1.2 to $>100 \mathrm{mg} \mathrm{L}^{-1}$ for $N$. australe and $N$. parvum, respectively (data not shown).

\section{Discussion}

The in vitro results obtained in this study demonstrate the effectiveness of DMI fungicides in the control of the conidial germination and radial mycelial growth of $D$. mutila, D. seriata, $N$. australe and $N$. parvum, species which are commonly associated with grapevine trunk diseases in Chile (Auger et al., 2004; Díaz et al., 2011; Morales et al., 2012; Torres et al., 2011).

Important differences among the DMI fungicide treatments were observed in this study. Based on the obtained $\mathrm{EC}_{50}$ values, tebuconazole, followed by myclobutanil and prochloraz applied alone, most effectively inhibited the conidial germination of $D$. mutila and D. seriata. The mixture of prochloraz with epoxiconazole improved the efficacy of prochoraz against Diplodia spp. Whether this improvement is due to a synergistic effect remains to be determined.

Previous reports have also concluded that tebuconazole and prochloraz were the most effective compounds against D. mutila, $D$. seriata, N. australe and N. parvum (Bester and Fourie, 2005; Savocchia et al., 2005; Bester et al., 2007; Auger et al., 2010; Amponsah et al., 2012). Additionally, our results agree with a recently published report (Pitt et al., 2012) indicating that tebuconazole and myclobutanil are very effective at controlling the mycelial growth of $D$. seriata and N. parvum in vitro.

Several differences in conidial germination and mycelial growth inhibition were observed among species and isolates. In general, the $\mathrm{EC}_{50}$ values were lower for mycelial growth inhibition than for conidial germination inhibition, but a number of exceptions were found. For example, myclobutanil was more effective against conidial germination than mycelial growth for $N$. australe (isolate $\mathrm{Vid}$ 1509), with $\mathrm{EC}_{50}$ values of 0.4 and $1.7 \mathrm{mg} \mathrm{L}^{-1}$ for the respective inhibitory actions.

Interestingly, most of the tested DMI fungicides were highly effective against the mycelial growth of Diplodia spp. and Neofusicoccum spp. Nevertheless, several important differences between the species of Diplodia were obtained, suggesting that it is not accurate to generalize the fungicidal effects obtained with a particular species of Diplodia to the genus level.

In summary, the results of this study suggest that the fungicides tebuconazole and myclobutanil, which are registered as control agents of grapevine powdery mildew and gray mold in Chile, possess considerable in vitro activity against $D$. mutila, $D$. seriata, N. australe and N. parvum. Prochloraz and prochloraz plus epoxiconazole also appear to be highly effective against these fungal species 
of the family Botryosphaeriaceae, which are commonly associated with trunk diseases of grapevines. However, DMI fungicides shown to be highly effective in vitro have occasionally performed poorly in field tests (Sosnowski et al. 2008; Pitt, 2012), and it is important to study the effectiveness of these DMI compounds in the vineyard before reaching any final conclusions.

\section{Acknowledgements}

This study was made possible by funding provided by ANASAC, Chile. The authors wish to thank Gladys Andrade, Iván Cortés, Andrea Morales, Alejandra Larach, Rocio Camps, Eduardo Salgado, Pontificia Universidad Católica de Valparaíso, Chile, and Gonzalo A. Díaz, Pontificia Universidad Católica de Chile, for their technical collaboration.

\title{
Resumen
}

\begin{abstract}
C. Torres, B. A. Latorre, P. Undurraga y X. Besoain. 2013. Evaluación de fungicidas DMI contra especies de Diplodia y Neofusicoccum asociadas con cancrosis por Botryosphaeria en la vid. 40(1):131-138. Las especies de Botryosphaeriaceae han sido ampliamente estudiadas y se considera un importante problema para el cultivo de la vid (Vitis vinifera) a nivel mundial. Este trabajo tuvo por objetivo estudiar la efectividad de inhibidores de la biosíntesis de esteroles, fungicidas DMI, en inhibir la germinación conidial y el crecimiento micelial de tres aislados de las especies Diplodia seriata y D. mutila, dos aislados de Neofusicoccum australe y uno de $N$. parvum, obtenidos de vides. Las concentraciones efectivas necesarias para inhibir en un $50 \%\left(\mathrm{EC}_{50}\right)$ y $90 \%\left(\mathrm{EC}_{90}\right)$, la germinación conidial y el crecimiento micelial, se estimaron por análisis de regresión lineal entre $\mathrm{x}=\log _{10}$ de la concentración de fungicida $\mathrm{e}$ $\mathrm{y}=$ el valor Probit del porcentaje de inhibición. Los resultados de este estudio mostraron que tebuconazol, miclobutanil, procloraz y procloraz más epoxiconazol tienen una considerable actividad in vitro contra D. mutila, D. seriata, N. australe y N. parvum. Estos compuestos DMI fueron capaces de detener la germinación conidial e inhibir el crecimiento micelial. Los valores de $\mathrm{EC}_{50}$ obtenidos para la germinación conidial fueron más altos que los valores de $\mathrm{EC}_{50}$ obtenidos para el crecimiento micelial, lo que sugiere que el micelio fue más sensible a los compuestos DMI que las conidias. Queda por estudiar la eficacia de estos compuestos DMI en los viñedos antes de llegar a una conclusión final.
\end{abstract}

Palabras clave: Cancrosis, enfermedades, fungicidas, myclobutanil, prochloraz, tebuconazole.

\section{References}

Amponsah, N.T., E. Jones, H. Ridway, and M. Jaspers. 2012. Evaluation of fungicides for the management of Botryosphaeria dieback diseases of grapevines. Pest Management Sciences 68:676-683.

Auger, J., M. Esterio, G. Ricke, and I. Pérez. 2004. Black dead arm and canker of Vitis vinifera cv. Red Globe caused by Botryosphaeria obtusa in Chile. Plant Disease 88:1286-1286.
Auger, J., I. Perez, and M. Esterio. 2010. Evaluation of fungicides as potential grapevine pruning wood protectors against the main grapevine trunk disease pathogen in Chile. Phytopathologia Mediterranea 49:130.

Besoain X., Torres C., Díaz G.A., and Latorre B.A. 2013. First report of Neofusicoccum australe associated with Botryosphaeria dieback of grapevine in Chile. Plant Disease 97:143.

Bester, W., and P.H. Fourie. 2005. Fungicide sensitivity of selected Botryosphaeria species 
from grapevine. South African Journal of Science 101:314.

Bester, W., P.W. Crous, and P.H. Fourie. 2007. Evaluation of fungicides as potential grapevine pruning wound protectors against Botryosphaeria species. Australasian Plant Pathology 36:73-77.

Díaz, G.A., and B.A. Latorre. 2013. Efficacy of paste and liquid fungicide formulations to protect pruning wounds against pathogens associated with grapevine trunk diseases. Crop Protection 46:106-112.

Díaz, G.A., D. Prehn, X. Besoain, E.R. Chávez, and B.A. Latorre. 2011. Neofusicoccum parvum associated with grapevine trunk diseases in Chile. Plant Disease 95:1032.

Larignon, P., F. Fontaine, S. Farine, C. Clément, and C. Bertsch. 2009. Esca and Black dead arm: two major actors of grapevine trunk diseases. Comptes rendus Biologies 9:765-783.

Ma, Z., D. Morgan, and T. Michailides. 2001. Effects of water stress on Botryosphaeria blight of pistachio caused by Botryosphaeria dothidea. Plant Disease 85:745-749.

Morales, A., B.A. Latorre, Piontelli E., and X. Besoain. 2012. Botryosphaeriaceae species affecting table grape vineyards in Chile. Ciencia e Investigación Agraria 39:445-458.

Pitt, W.M., M.R. Sosnowski, R.H. Yu Qiu, S. Savocchia, and C.C. Steel. 2012. Evaluation of fungicides for the management of Botryosphaeria canker of grapevines. Plant Disease 96: 1303-1308.

Pusey, P. L. 1989. Influence of water stress on susceptibility of nonwounded peach bark to Botryosphaeria dothidea. Plant Disease 73:1000-1003.

Savocchia, S., E.N. Laurent, B.J. Stodart, and C.C. Steel. 2005. Botryosphaeria canker and sensitivity to fungicides in vitro. $43^{\text {rd }}$ South African Society for Plant Pathology Congress. Mossel Bay, Programe and Abstract, 88.

Sierra, S., M.A. Mannoni, and V. Ligios. 2008. Studies on the susceptibility of pruning wounds to infection by fungi involved in grapevine wood diseases in Italy. Phytopathologia Mediterranea 47:234-246.

Sosnowski, M.R., M.L. Creaser, T.J. Wicks, R. Lardner, and E.S. Scott, 2008. Protection of grapevine pruning wounds from infection by Eutypa lata. Aust. J. Grape Wine Res. 14:134-142.

Stammler, G. and J. Speakman. 2006. Microtiter method to test the sensitivity of Botrytis cinerea to boscalid. Journal of Phytopathology 154:508-510.

Torres, C., B.A. Latorre, and X. Besoain. 2011. Prevalencia y severidad de muerte de brazos asociada a vides cv. Cabernet Sauvignon en las regiones de O'Higgins y Maule. XX Congreso Chileno de Fitopatologia. Santiago, Chile. Abstract.

Úrbez-Torres, J.R. 2011. The status of Botryosphaeriaceae species infecting grapevines. Phytopathologia Mediterranea 50:5-44.

Úrbez-Torres, J.R., and W.D. Gubler. 2011. Susceptibility of grapevine pruning wounds to infection by Lasiodiplodia theobromae and Neofusicoccum parvum. Plant Pathology 60:261-270.

Van Niekerk, J.M., Fourie, P.H., Halleen, F., and Crous, P.W. 2006. Botryosphaeria spp. as grapevine trunk disease pathogens. Phytopathologia Mediterranea 45:S43-S54.

Van Niekerk, J.M., Fourie, P.H., Halleen, F., and Crous, P.W. 2007. Susceptibility of grapevine pruning wounds to trunk pathogen infection in South Africa. Phytopathologia Mediterranea 46:102-128. 